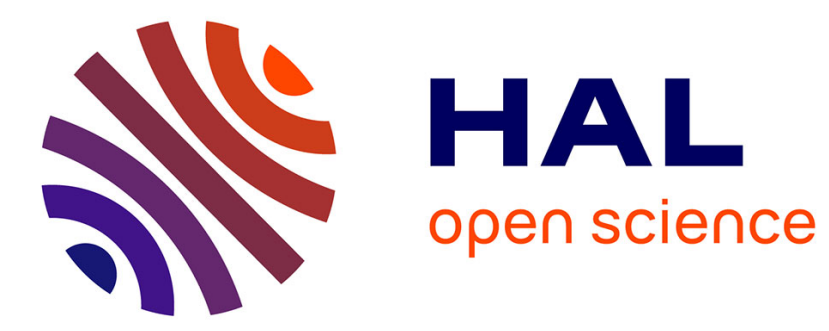

\title{
MÖSSBAUER EFFECT OF 61Ni IN SPINEL TYPE MAGNETIC OXIDES
}

\author{
H. Sekizawa, T. Okada, S. Okamoto, F. Ambe
}

\section{To cite this version:}

H. Sekizawa, T. Okada, S. Okamoto, F. Ambe. MÖSSBAUER EFFECT OF 61Ni IN SPINEL TYPE MAGNETIC OXIDES. Journal de Physique Colloques, 1971, 32 (C1), pp.C1-326-C1-327. 10.1051/jphyscol:19711108 . jpa-00213923

\section{HAL Id: jpa-00213923 https://hal.science/jpa-00213923}

Submitted on 1 Jan 1971

HAL is a multi-disciplinary open access archive for the deposit and dissemination of scientific research documents, whether they are published or not. The documents may come from teaching and research institutions in France or abroad, or from public or private research centers.
L'archive ouverte pluridisciplinaire HAL, est destinée au dépôt et à la diffusion de documents scientifiques de niveau recherche, publiés ou non, émanant des établissements d'enseignement et de recherche français ou étrangers, des laboratoires publics ou privés. 


\title{
MÖSSBAUER EFFECT OF ${ }^{61} \mathrm{Ni}$ IN SPINEL TYPE MAGNETIC OXIDES
}

\author{
H. SEKIZAWA, T. OKADA, S. OKAMOTO and F. AMBE
}

The Institute of Physical and Chemical Research, Yamato-Machi, Saitama, 351 Japan

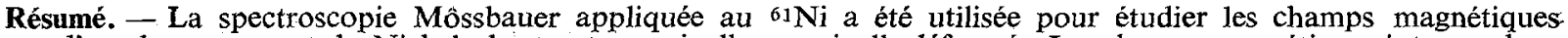
internes d'oxydes contenant du Nickel, de structure spinelle ou spinelle déformée. Les champs magnétiques internes dans des oxydes contenant des ions de Nickel en site octaédrique, ont été trouvés de l'ordre de 70 à $100 \mathrm{kOe}$. $\mathrm{Dans}^{\mathrm{NiCr}} \mathrm{O}_{4}$, où les ions de Nickel se trouvent sur des sites tétraédriques, nous avons mesuré un champ magnétique interne voisin de $450 \mathrm{kOe}$ à la température de l'Hélium liquide. Cette valeur semble être la plus élevée jamais trouvée pour le ${ }^{61 \mathrm{Ni}}$.
\end{abstract}

Abstract. - The Mössbauer spectroscopy of $61 \mathrm{Ni}$ was effectively utilized to investigate the internal magnetic fields in Ni-containing oxides with spinel or distorted spinel structure. The internal magnetic fields in oxides with the nickel ions in octahedral site were observed to be 70-100 kOe. In $\mathrm{NiCr}_{2} \mathrm{O}_{4}$, in which nickel ions are in tetrahedral site, an internal magnetic field amounting to $450 \mathrm{kOe}$ was observed at liquid $\mathrm{He}$ temperature. This value seems to be the largest one ever observed for ${ }^{61 \mathrm{Ni}}$.

I. Introduction. - In spite of many experimentally undesirable nuclear properties, ${ }^{61} \mathrm{Ni}$ can be a powerful probe in solid state physics as the only Mössbauer nuclide other than ${ }^{57} \mathrm{Fe}$ in the iron group transition elements $[1,2,3,4]$, especially in the studies of internal magnetic fields.

The purpose of the present paper is to discuss the Mössbauer effect of ${ }^{61} \mathrm{Ni}$ in various Ni-containing oxides with spinel (or distorted spinel) structure.

II. Experimental. - The nuclear reactions, ${ }^{58} \mathrm{Ni}(\alpha, \mathrm{p}){ }^{61} \mathrm{Cu}$

and ${ }^{58} \mathrm{Ni}(\alpha, \mathrm{n}){ }^{61} \mathrm{Zn} \quad \beta^{+}, \mathrm{EC} \cdot{ }^{61} \mathrm{Cu}$ were utilized to produce the source nuclide ${ }^{61} \mathrm{Cu}$. A thin $\mathrm{Ni}-\mathrm{V}$ (84-16) alloy disc of about $20 \mathrm{~mm}$ in diameter was irradiated for several hours with $21 \mathrm{MeV} \alpha$-particles from the $160 \mathrm{~cm}$ IPCR Cyclotron of this Institute, and was used as the source without annealing. The Ni-V (84-16) alloy crystallizes in f. c. c. structure and paramagnetic in nature. The specimens of various oxides were prepared by the convenient ceramic method, using nickel enriched with ${ }^{61} \mathrm{Ni}$ up to $80-90 \%$. An NaI(Tl) scintillation counter was employed to detect the transmitted radiation. The Mössbauer spectrometer made by Elron or the one by Hitachi was operated in constant acceleration mode with a 400 channel pulse height analyzer.

Because of the low resolution of the ${ }^{61} \mathrm{Ni}$ Mössbauer spectra, computer fitting of them to theoretical curves was an indispensable procedure to extract various parameters from the obtained spectra, Concerning the quadrupole moment of the excited state of ${ }^{61} \mathrm{Ni}$, the rough estimation of -2 for the ratio $Q_{\mathrm{ex}} / Q_{\mathrm{gr}}$ due to Erich [3], had been adopted tentatively in the analysis. Fortunately, the quadrupolar interactions in the spinels investigated turned out to be almost negligible compared with the magnetic interactions, except for a few cases mentioned in the text. The values of the isomer shift of the obtained spectra were also found to be of the order of the experimental uncertainty. Consequently, only the internal field is discussed in this paper, and the numerical values of the quadrupolar interaction and the isomer shift will not be presented.

III. Results and discussion. - The two groups of oxides with spinel (or distorted spinel) structure were investigated : the first group with the nickel ions in the octahedral site $\left(\mathrm{NiFe}_{2} \mathrm{O}_{4}, \mathrm{NiCo}_{2} \mathrm{O}_{4}, \mathrm{NiMn}_{2} \mathrm{O}_{4}\right.$ and $\mathrm{GreNi}_{2} \mathrm{O}_{4}$ ), and the second group with the nickel ions in the tetrahedral site $\left(\mathrm{NiCr}_{2} \mathrm{O}_{4}\right.$ and $\left.\mathrm{NiRh}_{2} \mathrm{O}_{4}\right)$.

1. THE SPINELS WITH NICKEL IONS IN THE OCTAHEDRAL SITE. $-\mathrm{NiFe}_{2} \mathrm{O}_{4}$ : The Mössbauer spectrum at $80^{\circ} \mathrm{K}$ is shown in figure 1 . It is an almost symmetric pattern

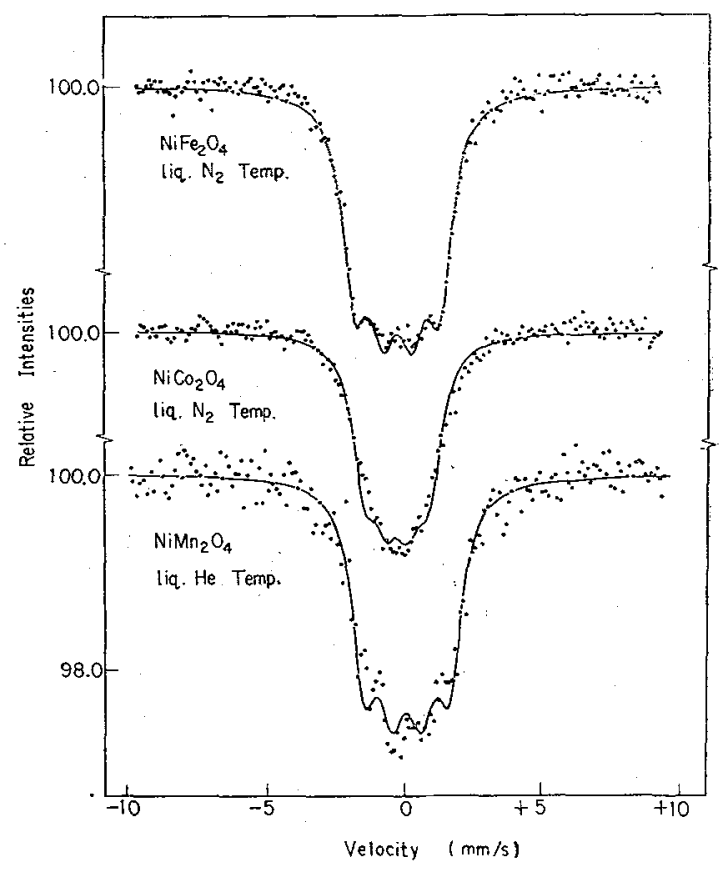

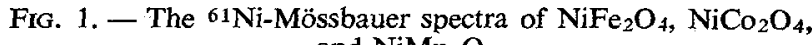
and $\mathrm{NiMn}_{2} \mathrm{O}_{4}$.

with noticeable peaks on the top, characteristic to a case with appreciable internal magnetic field $H_{i}$ and negligible electric freld gradient (EFG) effect. The value of $H_{\mathrm{i}}$ was found to be $94 \mathrm{kOe}$. This coincided with the value reported in [1], but the appreciable EFG effect reported therein had not been observed.

$\mathrm{NiCO}_{2} \mathrm{O}_{4}$ : The absorption pattern at $80^{\circ} \mathrm{K}$ is shown in figure 1 . The values of $H_{\mathrm{i}}$ were $73 \mathrm{kOe}$ and $87 \mathrm{kOe}$ at $80^{\circ} \mathrm{K}$ and at liquid $\mathrm{He}$ temperature, respectively. 
$\mathrm{NiMn}_{2} \mathrm{O}_{4}$ : According to the recent report by Boucher et al. [5], this spinel is incompletely inverse depending on the heat treatment. The fitting was made under the assumption of completely inverted ionic distribution, but the fitting at liquid He temperature was not very unsatisfactory with $H_{\mathrm{i}}$ of $97 \mathrm{kOe}$ as can be seen in figure 1 , and at $80^{\circ} \mathrm{K}$ the best fit was obtained with $H_{\mathrm{i}}$ of $72 \mathrm{kOe}$.

$\mathrm{GeNi}_{2} \mathrm{O}_{4}$ : The pattern at $80^{\circ} \mathrm{K}$, which is far above its reported Néel temperature of $16^{\circ} \mathrm{K}$, was slightly asymmetric suggesting that the EFG effect is working.

2. THE SPINELS WITH NICKEL IONS IN TETRAHEDRAL SITE. - $\mathrm{NiCr}_{2} \mathrm{O}_{4}$ : As is well known, this oxide has cubic spinel structure at temperatures higher than $310^{\circ} \mathrm{K}$, below which it becomes tetragonal due to the Jahn-Teller effect of the $\mathrm{Ni}^{2+}$ ions in the tetrahedral sites. The ferrimagnetic Curie temperature is reported to be about $80^{\circ} \mathrm{K}$. According to Prince [6], the spin structure investigated by neutron diffraction is very complicated but the detailed spin structure is still unknown. At $80^{\circ} \mathrm{K}$, the spectrum seems to be slightly asymmetric with a width wider than the single line cases, as can be seen in the upper part of figure 2 .

The most remarkable feature of this spinel is the widening of the pattern on cooling down to the liquid He temperature, as shown in the lower part of the same figure. The value of the internal magnetic field determined by the fitting amounted to $450 \mathrm{kOe}$, which seems to be the largest one ever reported for ${ }^{61} \mathrm{Ni}$. Without data with an applied external magnetic field, detailed discussion of the possible origin of such a large field should be premature. However, contribution from the only incompletely quenched orbital moment of the Jahn-Teller distorted $\mathrm{Ni}^{2+}$ ions might be a possible mechanism to explain it.

$\mathrm{NiRh}_{2} \mathrm{O}_{4}$ : The transition temperature from cubic to tetragenal symmetry is $380^{\circ} \mathrm{K}$, and the antiferromagnetic Néel temperature is reported to be $18^{\circ} \mathrm{K}$. The spectrum taken at $80^{\circ} \mathrm{K}$ showed a noticeable asymmetry.

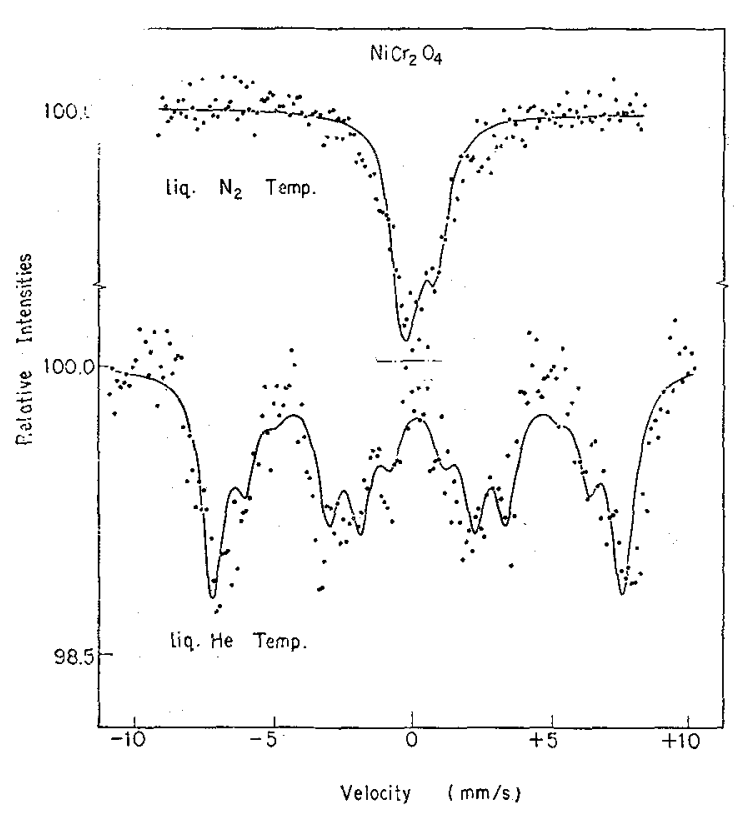

FIG. 2. - The 61Ni-Mössbauer spectra of $\mathrm{NiCr}_{2} \mathrm{O}_{4}$.

IV. Conclusion. - A striking difference in magnitude of the internal magnetic field at ${ }^{61} \mathrm{Ni}$ nuclei has been observed between the spinel oxides with nickel ions in the octahedral site and $\mathrm{NiCr}_{2} \mathrm{O}_{4}$ with its nickel ions in the tetrahedral site. The former shows an internal magnetic field of the order of 70-100 kOe and a negligible EFG effect. The latter shows an internal magnetic field as high as $450 \mathrm{kOe}$, the origin of which is not yet established.

Acknowledgment. - The authors wish to express their sincere gratitude to the members of the Cyclotron Laboratory of this Institute for their earnest support given to this work. They are gratefal also to Professors $H$. Watanabe and N. Saito for their continuing interest and encouragement.

\section{References}

[1] Travis (J. C.) and SpiJkerman (J. J.), Mössbauer Effect Methodology, Vol. 4, Plenum Press (New York, 1968), 237.

[2] Erich (U.), Kankeleit (E.), Prange (H.) and HÜfNer (S.), J.. Appl. Phys., 1969, 40, 1391

[3] ERICH (U.), Z. Phys., 1969, 227, 25.
[4] Obenshain (F. E.), Love (J. C.) and Czjzek (G.), Proceedings of the $11 \mathrm{th}$ International Conference on Low Temperature Physics, Vol. 1, Univ. of St. Andrews (1968), 532.

[5] Boucher (B.), Buhl (R.) and Perrin (M.), J. Phys. Chem. Solids, $1970,31,363$.

[6] Prince (E.), J. Appl. Phys., 1961, 32, 68 S. 